Res Pública Revista de Historia de las Ideas Políticas

ISSN: $1131-558 \mathrm{X}$

https://dx.doi.org/10.5209/rpub.75410

\title{
J. A. Fernández López, El archivo y la ficción. Historia, identidad y literatura en Danilo Kiš, Madrid, Guillermo Escolar Editor, 2020, 232, pp.
}

Cualquier ejercicio indagatorio que tenga como objetivo definir la temática fundamental de la obra de Danilo Kiš (Subotica, 1935-Paris, 1989) se enfrenta al reto de no caer en las redes de la confusión categorial. Variantes de un comprometido lamento por los caídos de la historia, los personajes, hechos, figuras del espíritu, ideas y valores que nutren un universo novelístico que trasciende los límites entre lo usualmente concebido como real o ficcional. A ello no escapa, por supuesto, el contenido identitario y ético-político de la poética kisheana. La visión del individuo a merced del totalitarismo en el siglo XX se presenta en Kiš como una singular lectura de la condición judía -ejemplar, familiar e histórica- como epítome de todas las víctimas del fascismo y del estalinismo. El judaísmo como problema en la literatura de Danilo Kiš es el reverso victimizado del totalitarismo representado en sus obras, pero no sólo esto. En tiempo real, en la propia vida de un autor que asumió la escritura como una aventura estética y existencial, vivida en el marco cultural y político de la Yugoslavia de la segunda mitad del siglo pasado, también significará el reverso victimizado de un nacionalismo que ya alentaba inconscientemente el incendio que devastaría y destruiría la antigua república yugoslava.

El estudio del profesor de la Universidad de Murcia José Antonio Fernández es la primera aproximación sistemática en español -más allá de artículos y reseñas-a la obra de este autor genial y necesario. Su trabajo es un recorrido por la vida y la obra de este escritor yugoslavo, por la excepcionalidad del carácter de su compromiso artístico, por su brillante capacidad de innovación literaria y su profunda meditación sobre la historia, la cultura y la condición humana. El universo de Kiš, los tópicos fundamentales que están presentes en su obra, merced al proceso de lectura que El archivo y la ficción opera, se tornan elementos dinámicos que permiten recrear, más allá de la historia personal del autor de Una tumba para Boris Davidovich, una particular versión de la historia del siglo XX. Testimonio de la intransigencia ideológica y de los delirios nacionales, la narrativa de Kiš, estimulada por una personal ironía, realiza una reconstrucción de la historia desde una memoria que es compasiva y creativa a la vez. Admirada por lectores y críticos, rechazada vehementemente por el establishment de su propio país, controvertida siempre, fue la suya una empresa literaria indisolublemente ligada a su propia vida, una vida bajo la sombra de la historia del siglo XX. El presente ensayo enfatiza el convencimiento kisheano de que la literatura no podía ser más que la descripción y la condena de la injusticia, de que la tarea del escritor es el incansable esfuerzo por levantar acta de la barbarie de nuestra época. Frente a todo intento de reducir al ser humano a la condición de hombre unidimensional, Kiš reivindicará una literatura que dice lo mejor de sí al representar la pluriforme riqueza de la singularidad; una literatura concebida como recreación de un mundo roto en pedazos por el ensueño de la totalidad. Confrontados con la cosificación de los seres humanos, los libros de Kiš representan un memento pormenorizado, exhaustivo, con la visibilidad litúrgica de una letanía, de unos personajes que simbolizan todas las vidas truncadas por la violencia de la historia. Una actualización de vidas malhadadas; su recuperación moral para una historia que siempre tiende a olvidarlas.

El Archivo y la ficción concibe la lectura de la obra de Kiš como un ejercicio donde la filosofía de la historia se entrelaza con un estudio de filosofía de la literatura y teoría de la representación en la búsqueda de una explicitación de la idea de identidad ("El arte de la novela"). De aventura literaria y existencial puede calificarse la experiencia de subvertir intelectualmente el orden de las cosas dadas. Kiš describe líricamente el procedimiento generador de su propia poética como la liberación de una presión metafísica, una "sangría en la aorta" allí donde la presión es más insoportable. Desde sus inicios juveniles con La buhardilla, pasando por las novelas que componen el Circo familiar, hasta Una tumba para Boris Davidovich y La Enciclopedia de los muertos, la obra de Kiš se despliega como una búsqueda de respuestas a preguntas "poéticas y metafísicas" que conforman una suerte de pulsión obsesiva siempre abierta. Así como el trágico cúmulo de circunstancias de su propio destino personal le exigieron preguntarse por la raza, el entorno familiar o las vicisitudes históricas del clan familiar, la coetaneidad del autor con el totalitarismo se tornó idea intelectual obsesiva ("Circo familiar"). Sin embargo, mientras que la problemática identitaria personal y familiar, aun no habiendo sido cerrada por su representación artística, tan solo liberada de su presión, se había convertido en "algo indoloro y desprovisto de actualidad", una recurrencia obsesiva nueva y recóndita convertía la temática totalitaria en una "pesadilla moral y moralista". ¿Por qué? Si hablar del fascismo en los libros de un yugoslavo de origen judío no tenía mayor carácter revelador que el de la concreción histórica y artística de la propia identidad cultural y política, relatar el horror del Gulag supondrá un evidente salto al vacío ante la mirada desaprobatoria de un amplísimo audito- 
rio, tanto nacional como extranjero. Kiš describe el desarrollo de esta nueva conciencia moral y artística como una clase singular de rechazo a un reflejo condicionado "pavloviano"; la conciencia, tornada "peso lírico", de una profunda vergüenza y arrepentimiento.

Especial mención merece el capítulo que Fernández López dedica a la acusación de plagio que sufrirá Kiš por parte del establishment literario serbio tras la publicación de Una tumba, y que tendrá como respuesta su demoledora Lección de anatomía y el autoexilio en Francia hasta su muerte ("Alfred Dreyfus en Belgrado”). En la Yugoslavia de 1976 toda postura ideológica estaba condicionada por el nacionalismo. Adentrarse en las catacumbas del estalinismo soviético para recuperar a sus víctimas, a los caídos olvidados de la historia oficial, informar en clave de ficción, como hacía Una tumba para Boris Davidovich, de la destrucción del Komintern y del exterminio, durante las purgas del año 1937 , de sus miembros más cualificados, poco o nada tenía que ver con la Yugoslavia de Tito. Y, sin embargo, la acusación de "plagiar", "modificar" o "releer" lanzada contra Kiš, ya fueran los supuestos clásicos de la historia oficial marxista, la novelística de algún autor soviético o la obra de James Joyce o Jorge Luis Borges expresaba más bien en un fondo no demasiado profundo los atavismos del clan sólo superficialmente solapados, en este caso el antisemitismo y la nostalgia paneslavista serbia. $\mathrm{Y}$, sin embargo, aquello que los censores de Danilo Kiš tan sólo se atrevieron a barruntar, sin comprender del todo su alcance, fue la genial transformación que una breve obra maestra literaria como Una tumba fue capaz de operar con un periodo tan decisivo de la historia contemporánea como el que abordaba. La maestría literaria Kiš se puso al servicio de una empresa singular de comprensión e iluminación: convertir la historia soviética en una nueva mitología de nuestra civilización, más allá de los clichés ideológicos -o "hábitos pavlovianos"-al uso. A la inconmensurable catástrofe histórica y humana perpetrada en la Rusia soviética en la década de los años treinta y cuarenta, nunca se le concedió, durante la posguerra y la Guerra Fría, el interés que hubiera sido considerado justo a tenor de la lectura que sí se hizo de los crímenes del nacionalsocialismo. Un principio de hermenéutica asimétrica se instaló en entre Kolymá y
Auschwitz, entre el Lager y el Gulag, un desfase del interés epistemológico que, desgraciadamente, condenó a las víctimas del estalinismo a una segunda muerte, la del olvido. El enorme valor de Una tumba para Boris Davidovich reside en la singular recuperación ética que su maestría literaria opera: la recuperación para el conocimiento y la historia de las víctimas olvidadas. La sutil perspectivación de Kiš, su énfasis en la imaginación y el detalle, combinado con la distancia irónica, consigue que el sentimiento sea pensado. Construida como un extenso poema dramático, la obra tiene la virtud de redefinir la tragedia como un medio que recupera a las víctimas "haciendo hablar al tiempo", equiparando el arte a la realidad humana. Del silencio tras las desapariciones y las purgas, del silencio del Gulag, surge la palabra, la comprensión estética allí donde el ethos enmudece.

En "El árbol del conocimiento" y a modo de epílogo, el presente ensayo vuelve a incidir en cómo -paradojas del arte y de la ética- el narrador que se sirve de la ficción está comprometido con el desvelamiento de la verdad histórica. El espíritu de la narración, que en Thomas Mann hace sonar las campanas de Roma, es de la misma naturaleza espiritual que el Angelus novus de W. Benjamin. Transformando el gran relato en microhistoria, ese archivero o escribano que es el autor de ficción no recrea los grandes imperios perdidos ni las culturas sepultas, no ejerce de autor de best sellers históricos. Reconstruyendo restos, juntando ruinas, mostrando vestigios, encuentra también las sombras de aquellos caídos a los que la historia oficial no recuerda. Salvar y preservar lo que está a punto de desaparecer, es el propósito de un autor a quien lo que le interesa "no es la labor del reportero, sino la investigación y las excavaciones del arqueólogo". No es extraño pues que el compromiso artístico iniciado en Una tumba culminara en Kiš en los relatos de la Enciclopedia de los muertos, historias "de escribanías, de cenotafios, de las tumbas vacías". Salvar del olvido lo individual es la empresa intelectual de un moralista que se resiste a que el discurso de la totalidad anule la singularidad anónima de las víctimas de la historia, y para ese fin, una literatura que insista en lo particular, en la desemejanza, en la "diferencia esencial" de cada ser humano.

David Soto Carrasco 